\title{
Identifying fast ice flow from landform assemblages in the geological record: a discussion
}

\author{
Jane K. Hart \\ Department of Geography, University of Southampton, Southampton SO17 1BJ, England
}

\begin{abstract}
Different types of fast ice flow (both spatial and temporal) in valley glaciers (surging glaciers, tidewater glaciers and deforming-bed glaciers) and ice sheets (ice streams and deforming-bed ice-sheet flow) are discussed briefly. Although there are unlikely to be any specific individual landforms associated with fast ice flow, there may be landform assemblages.

At valley glacier scale, it is suggested that there are two landform assemblages: (1) an ice-thrust type, dominated by bulldozed push moraines and hummocky moraines (associated with glaciers with a high supraglacial sediment supply, a coarse-grained substrate and a coarse-grained proglacial sediment wedge); and (2) a bed-flow type dominated by "squeeze" push moraines, flutes and drumlins (associated with glaciers with a low supraglacial sediment supply and fine-grained substrate). The ice-thrust type alone is only associated with discontinuous fast flow (on both rigid and deforming beds); whilst the bed-flow type is associated with both continuous and discontinuous fast flow.

It is suggested that these two landform assemblages may also be indicative of fast ice flow at ice-sheet scale, in particular the bed-flow style. If that is the case, then discontinuous fast ice flow may be indicated by the ice-thrust landform assemblage and the bed-flow style where drumlins are present.

It is also suggested that specific evidence for ice streams includes the distinctive landform assemblages within valley or fan-like locations, and a predictable pattern of velocity reflected by drumlin elongation ratios.
\end{abstract}

\section{INTRODUCTION}

A key element in the understanding of glacial dynamics and its link with climatic change is an understanding of "fast ice flow". A dramatic illustration of this today is the Siple Coast ice streams of the West Antarctic ice sheet, which drain most of the ice from the slow-moving ice sheet. On a smaller scale, the understanding of the mechanisms that cause glacier surges is also an important factor in understanding glacier behaviour. Additionally, it has been suggested that during the Quaternary many of the large ice sheets moved over a deforming bed (e.g. southern lobes of the Laurentide and southeastern portions of the Fennoscandian ice sheets), which resulted in fast ice flow (e.g. Alley, 1991), but the spatial or temporal scale of this fast ice flow is not known.

In this paper, the landform assemblages (and associated sediments) from all scales of glacier are discussed. To begin with, the different types of fast ice flow are summarized, then the geomorphologies from modern surging glaciers are described and some tentative suggestions concerning the identification of fast ice flow in ancient glaciers are put forward.

Table 1. Different types of fast ice flow

\begin{tabular}{|c|c|c|c|c|}
\hline \multicolumn{2}{|c|}{ Type of fast-flowing glacier } & \multirow{2}{*}{$\begin{array}{l}\text { Type of fast ice flow } \\
\text { Discontinuous }\end{array}$} & \multirow{2}{*}{$\begin{array}{l}\text { Modern example } \\
\begin{array}{l}\text { Variegated Glacier, Alaska } \\
\text { (Kamb and others, 1985) }\end{array}\end{array}$} & \multirow{2}{*}{$\begin{array}{l}\text { Ancient example } \\
\begin{array}{l}\text { Black Rapids, Alaska } \\
\text { (Reger and others, 1993) }\end{array}\end{array}$} \\
\hline Valley glaciers & Surging valley glaciers & & & \\
\hline & Tidewater water glaciers & Discontinuous & $\begin{array}{l}\text { Columbia Glacier, Alaska } \\
\text { (Meier and Post, 1987) }\end{array}$ & ? \\
\hline & Deforming-bed glaciers & Continuous & $\begin{array}{l}\text { Breiðamerkurjökull, Iceland } \\
\text { (Boulton, 1979) }\end{array}$ & ? \\
\hline \multirow[t]{3}{*}{ Ice sheets } & "Surging" ice streams & Discontinuous & $\begin{array}{l}\text { Ice Stream C, Antarctica } \\
\text { (Shabtaie and Bentley, 1987) }\end{array}$ & $\begin{array}{l}\text { Lobes of the Laurentide ice sheet } \\
\text { (Clayton and others, 1985)? }\end{array}$ \\
\hline & "Steady" ice streams & Continuous & $\begin{array}{l}\text { Jakobshavn Isbræ, Greenland } \\
\text { (Whillans and others, 1993) }\end{array}$ & $\begin{array}{l}\text { Ice streams from the Western Fennoscandian } \\
\text { ice stream (Dowdeswell and others, 1996)? }\end{array}$ \\
\hline & $\begin{array}{l}\text { Deforming-bed fast } \\
\text { ice-sheet flow }\end{array}$ & Continuous & ? & $\begin{array}{l}\text { East Anglia,England } \\
\text { (Hart and Boulton, 1991)? }\end{array}$ \\
\hline
\end{tabular}




\section{FAST ICE FLOW}

Fast ice flow is a very common feature of glaciers and can occur at all temporal and spatial scales. The different types of fast ice flow will now be discussed (see Table 1).

\section{Valley glaciers}

There are a number of different types of fast ice flow associated with valley glaciers: surging glaciers, tidewater glaciers and deforming-bed glaciers. On a small scale, short-term (1-10 years) velocity increases in valley glaciers are known as surges. Variegated Glacier, Alaska (resting on a rigid bed) has a quiescent phase velocity of $0-73 \mathrm{ma}^{-1}$ (Sharp, 1988), whilst during its surge phase velocities increase to a maximum of $23000 \mathrm{~m} \mathrm{a}^{-1}$ (Kamb and others, 1985). There have been many theories to explain this phenomena, however recent research can be summarized into two models, based on either changes in subglacial water flows (Kamb and others, 1985) or the subglacial deforming bed (Clarke and others, 1984).

Many tidewater glaciers also undergo fast ice flow, but usually during rapid retreat. Meier and Post (1987) showed that the temperate tidewater glaciers of Alaska and Chile appeared to go through a cycle: (1) stable position with the margin at the head of the fjord; (2) slow advance; (3) stable extended position; and (4) rapid retreat, during which time the glacier may move at surge velocities (e.g. Columbia Glacier, Alaska, $14 \mathrm{~m} \mathrm{~d}^{-1}$ ). In a similar way to surges, this cycle is not related to climatic changes (Meier and Post, 1969).

Subsequently, evidence for a deforming bed has been found at Columbia Glacier, both beneath the glacier from in situ drilling studies (Humphrey and others, 1993) and from studies from the foreland (Hart and Smith, 1997). It is not known how this affects the tidewater glacier cycle, nor whether a deforming bed is common to tidewater glaciers. However, it is likely the tidewater "surging" occurs on hard and soft rocks and the deforming bed is important, in a similar way to terrestrial surging glaciers.

Glaciers resting on deformable beds can also be described as fast ice flow (e.g. Breiðamerkurjökull, Iceland; Boulton, 1979). Although, their flow is nowhere near as fast as surging glaciers (flow is approximately $100 \mathrm{~m} \mathrm{a}^{-1}$ ), it is faster than rigid bedded glaciers (e.g. the Haut Glacier d'Arolla, Switzerland flows at approximately $10 \mathrm{~m} \mathrm{a}^{-1}$, Harbor and others, 1997). However, since their flow is only recently being monitored, it is not known as yet if this fast flow is continuous or discontinuous. However, in this paper, their flow will be assumed to represent steady-state continuous semi-fast flow.

\section{Ice streams and ice sheets}

Ice streams are large-scale features (surface area about $15000 \mathrm{~km}^{2}$ ) and have a typical velocity of over $400 \mathrm{~m} \mathrm{a}^{-1}$ (e.g. Ice Stream B, $800 \mathrm{~m} \mathrm{a}^{-1}$, Whillans and others, 1987; Rutford Ice Stream, $>400 \mathrm{ma}^{-1}$, Doake and others, 1987). They usually (although not necessarily) lie in deep channels with beds above sea level and terminate either in an ice shelf or a floating ice tongue. Some ice streams are bedrock controlled, whilst others (e.g. Siple Coast ice streams, West Antarctica) are not. The reason for the fast flow is not completely understood, however most researchers would argue that it is due to the presence of a saturated deforming layer (Alley and others, 1986).

It has also been shown that this fast flow is not necessarily continuous and from the study of radar images of buried crevasses, the currently slow-moving Ice Stream C, has been pos- tulated to have flowed much faster in the past (Shabtaie and Bentley, 1987). However, some ice streams seem to flow fast continuously, e.g. Jakobshavn Isbræ, Greenland (Whillans and others, 1993) (area $9000 \mathrm{~km}^{2}$, velocity $8360 \mathrm{~m} \mathrm{a}^{-1}$; Lingle and others, 1981). Thus, some ice streams experience continuous fast flow, whilst others undergo discontinuous fast flow ("surging" behaviour). However, the cause of this is not known.

Additionally, the fastest part of the ice sheet (not including ice streams) occurs just up-glacier from the margin. The equilibrium line altitude velocity for the current Greenland ice sheet (based on a rigid bed) was calculated to be $90 \mathrm{~m} \mathrm{a}^{-1}$ by Dahl-Jensen (1989) and 100-150 $\mathrm{ma}^{-1}$ by Bamber and others (1997). In Antarctica, there are fast-flowing fan-shaped areas (around the coast) which may be ice streams, where the ice velocity has been modelled to be $100-400 \mathrm{~m} \mathrm{a}^{-1}$ (Budd and Warner, 1996). Although this is much slower than the ice streams, it is much faster than the rest of the ice sheet.

\section{IDENTIFICATION OF FAST ICE FLOW ASSOCIATED WITH VALLEY GLACIERS}

In order to study the geomorphology associated with valley glaciers, modern glacier forelands can be investigated. The results from a number of studies are summarized below.

\section{Surging glaciers}

Numerous authors have suggested that surging glaciers produce a distinctive geomorphology (e.g. Sharp, 1988) including push moraines, stacked englacial debris bands, crevasse diapir ridges, hummocky moraines, sediment gravity-flow deposits from supraglacial melt-out tills, flutes and concertina eskers, as well as deformed medial moraines on the glacier.

Although many individual landforms have been identified as being associated with surging glaciers, almost all the features have also been similarly associated with non-surging glaciers (with the exception of deformed medial moraines and concertina eskers, both of which have a low preservation potential). In particular, push moraines are almost ubiquitous to the proglacial environment and, on their own, are not indicative of surging glaciers.

Hart and Smith (1996) investigated the forelands of a number of surging glaciers and found there were two distinct styles of landform assemblage:

(a) Ice-thrust type: Many surging glaciers do produce a landscape similar to that described above, e.g. a landscape dominated by hummocky moraines, bulldozed push moraines, with very little till or subglacial landforms. A good example of this is from Penckbreen, Svalbard (Hart and Watts, 1997) (Fig. la).

It is suggested that the compression at the ice margin leads to dramatic deformation of the ice; this allows subglacial material to be thrust up to the surface along debris bands (later to melt out to form hummocky moraines) and, if a deforming bed is present, subglacial debris can move up through crevasses to form crevasse diapirs. The ice will also compress any pre-existing proglacial sediment and form bulldoze-type push moraines. Although a deforming bed may be present in this type of surge (and may be a very important component of it), sediment is redistributed from the subglacial into the supraglacial environment via ice thrusting (Fig. 1b).

(b) Bed flow type: However, many glacier forelands do not 
a) Penckbreen

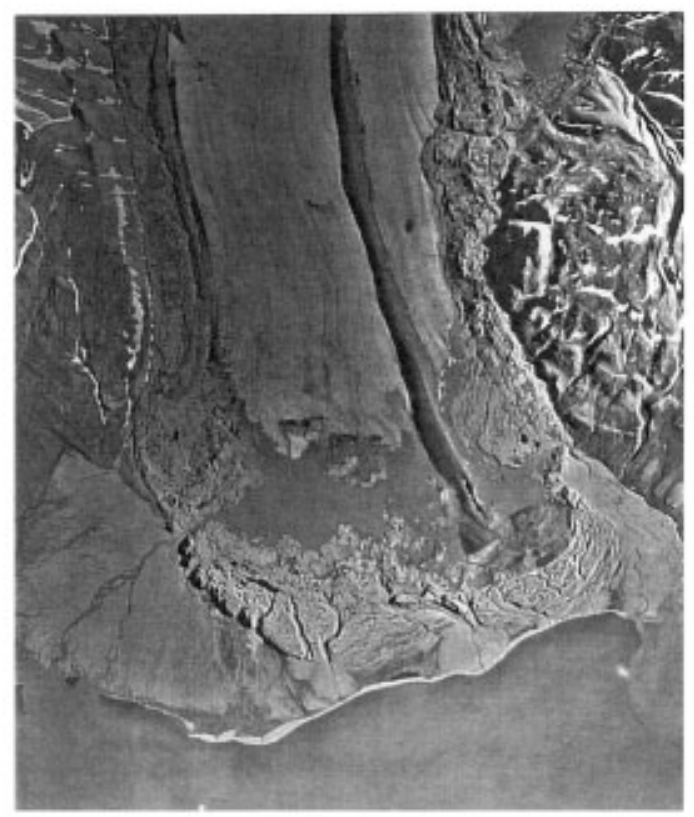

c) Fjallsjökull



b)

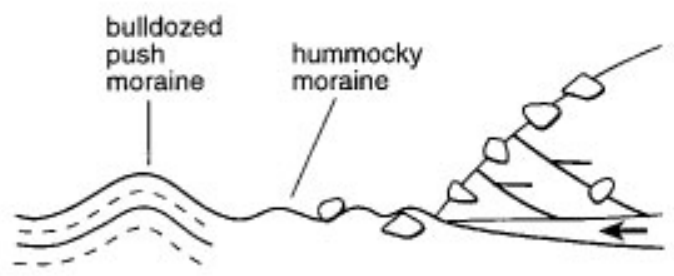

d)

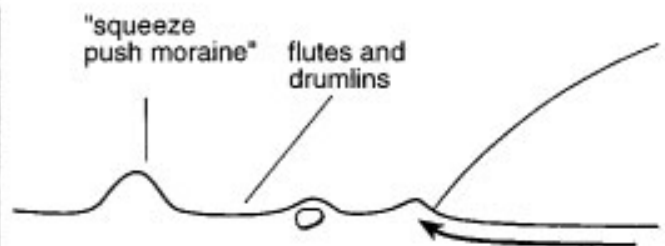

Fig. 1. Schematic diagram to show the different styles of landform assemblage associated with fast ice in valley glaciers. Ice-thrust type associated with surging glaciers: (a) Penckbreen, Svalbard; (b) cross-section. Bed-flow type associated with surging glaciers, tidewater glaciers and deforming-bed glaciers: (c) Fjallsjökull, Iceland (deforming-bed glacier); (d) cross-section.

show the "typical" surge-landform assemblage discussed above. A good example of this is Vestari-Hagafellsjökull, Iceland (Hart, 1995a) and others include Seftrömbreen (Cora Island), Svalbard (Boulton and others, 1996); Eyjabakkajökull, Iceland (Croot, 1988); and Trapridge Glacier, Yukon Territory, Canada (Clarke and Blake, 1991). The geomorphology at these sites is dominated by "squeeze" push moraines, subglacial lineations and subglacial till.

It is suggested that these glaciers respond to an increase in velocity by subglacial bed movement. Most of the sediment remains within the subglacial environment and this sediment is moved to the front of the glacier to form "squeeze" push moraines.
Both styles of surge landform assemblage may form crevasse diapirs associated with crevasses formed during active movement and ice disintegration. These form where a deforming bed is present.

\section{Tidewater glaciers}

The landform assemblage associated with tidewater glaciers has received far less attention, because the geomorphology is normally only preserved on islands. Hart and Smith (1997) were able to study part of the foreland of Columbia Glacier, which was deglaciated from 1974-86. The geomorphology at this site reflected the fast retreat part of the cycle (Columbia Glacier has undergone dramatic retreat since 
the early 1970s; Post, 1975). The foreland consisted of small "squeeze" push moraines at the palaeoglacier margin with flutes, drumlins and crevasse diapirs formed beneath the glacier. However, they were only able to study the geomorphology associated with the rapid retreat part of the tidewater-glacier cycle and were not able to show how the geomorphology changed (if at all) over the whole cycle.

\section{Deforming-bed glaciers}

Glaciers which rest on deformable beds and which periodically advance and retreat due to climate change (not surging), also have a distinctive geomorphology. They typically have "squeeze" push moraines, flutes and drumlins and no hummocky moraines (e.g. Breiðamerkurjökull, Iceland, Boulton, 1979; Fjallsjökull, Iceland; Fig. 1c). Crevasse diapirs have also been reported from this type of glacier (e.g. Exit Glacier, Alaska; Hart, 1995b), but having lower densities than the tidewater and surging glaciers.

\section{Comparison of different geomorphologies associated with discontinuous and continuous fast ice}

From the discussion above, it would seem there is no distinct geomorphology associated with surging or fast-flowing glaciers. The ice-thrust type landform assemblage is probably only associated with surging glaciers (but further studies are needed to prove this), whilst the geomorphology associated with the bed-flow type from surging glaciers, tidewater glaciers and deforming-bed glaciers are almost identical (Fig. 1b) with the exception of the lower density of crevasse diapirs (which generally have a low preservation potential).

Thus, during continuous or discontinuous fast flow, sediment can be carried mostly through the glacier (ice-thrust type; Fig. 1b) or through the deforming layer (bed-flow type; Fig. ld). Several authors (e.g. Hart, 1995b; Alley and others, 1997) have argued there is an interrelationship between the deforming layer and the debris-rich basal ice layer. The two geomorphologies found associated with fast ice may represent the end members of a wet-sediment-frozen-sediment continuum.

These geomorphologies do not seem to be related to thermal conditions, as both can be found associated with temperate (e.g. ice-thrust type: Eyjabakkajökull, Iceland; bedflow type: Vestari-Hagafellsjökull, Iceland) and sub-polar (e.g. ice-thrust type: Penckbreen, Svalbard; bed-flow type: Seftströmbreen, Svalbard) glaciers. Instead, grain-size, supraglacial sediment supply and proglacial sediment architecture seem to be important. The ice-thrust surging glaciers in this study tend to have a high supraglacial sediment supply, a coarse-grained subglacial sediment and a wedge of coarsegrained proglacial sediment; in contrast, bed-flow surging glaciers, tidewater glaciers and deforming-bed glaciers tend to have little supraglacial sediment, fine-grained subglacial sediment and no significant proglacial coarse-sediment wedge. Clearly, these three features may be related.

Iverson (1993) and Iverson and Semmens (1995) have suggested that regelation into sediments must be a very important process in debris entrainment into the ice. Alley and others (1997) have suggested that grain-size is important in this process and have suggested that under normal to rapid basal melting, $0.1 \mathrm{~m}$ of medium- to coarse-grained till and up to $1 \mathrm{~m}$ of gravel could be incorporated into the glacier, whilst fine-grained sediments would not be incorporated.

Given this, I propose the following scenarios: (a) During the surge in areas of coarse-grained marginal sediment, material is regelated into the glacier and moved up through debris bands on to the surface. This may be helped by the presence of a cold toe. At the same time, bulldozing of a wedge of proglacial sediments occurs. When the ice melts, the coarse-grained material litters the landscape (hummocky moraine), added to which is usually the presence of (usually coarse-grained) supraglacial debris. During the next surge, another coarse-grained "bed" and proglacial wedge has been produced, so the process becomes self-sustaining.

(b) During the surge in areas of fine-grained marginal sediment, material remains within the deforming layer and is moved out to form "squeeze" push moraines. There is little sediment entrainment, so little hummocky moraine is produced.

These two examples represent two extremes and there are probably many intermediate geomorphologies in between them.

\section{IDENTIFICATION OF FAST ICE FLOW ASSOCIATED WITH ICE SHEETS}

It is far more difficult to observe the geomorphology associated with modern ice sheets, and so evidence from the Quaternary needs to be included. I tentatively suggest, from an investigation of the Quaternary evidence, that there are three types of fast ice flow (see Fig. 2):

(a) Rigid-bed ice stream/outlet glacier: These are controlled by bedrock topography and, as a result, are the most constant in both space and time. A Quaternary example may be the bedrock-controlled outlet glaciers along the west coast of Norway (Fennoscandian ice sheet), which

a

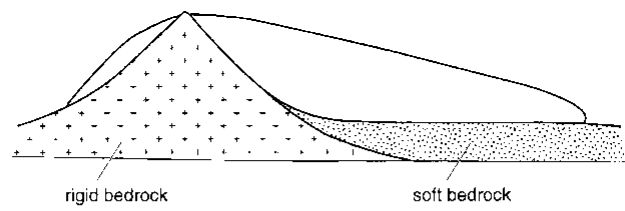

b

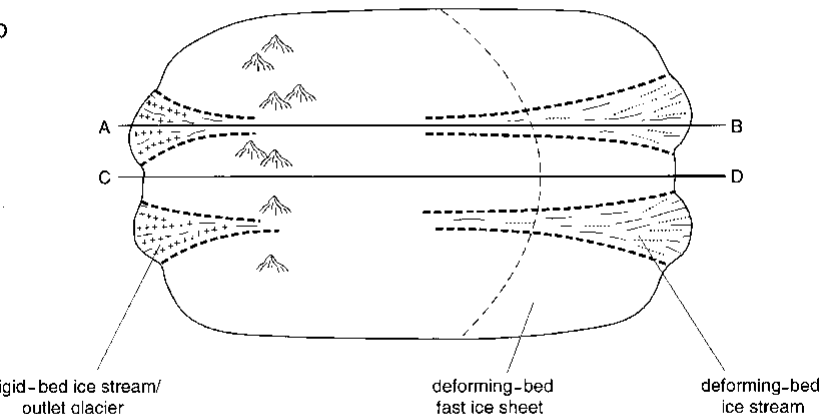

$\mathrm{C}$

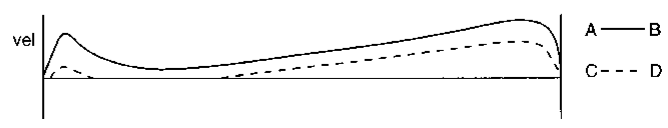

Fig. 2. Schematic diagram to show the different types of theoretical fast ice associated with a large land-based ice sheet: (a) cross-section; ( $b$ ) plan view with two transects $A B$ and $C D$; (c) velocity along two transects, $A B$ and $C D$. 




i

$20 \mathrm{~km}$

Fig. 3. Laurentide ice sheet with a map of the drumlins of New York State (after Slater, 1929).

are thought to have been constant in space and time and produced a series of till deltas along the continental margin (Dowdeswell and others, 1996). The typical landform-sediment assemblage consists of thin and patchy deforming-bed till and drumlins confined to valley-floor locations.

(b) Deforming-bed ice streams: These are not controlled by the bed-rock topography and therefore are mobile; these are probably the most variable in space and time. A Quaternary example may be the eastern/Baltic Sea area of the Fennoscandian ice sheet (Kleman and others, 1997). The typical landform-sediment assemblage consists of drumlins (and in places, deforming-bed till) confined to a valley-shaped or fan-shaped area.

(c) Deforming bed: This part of the ice sheet undergoes more steady-state semi-fast ice, but is not within an ice stream. In the model predictions by Boulton and others (1985), they calculated an ice velocity of over $400 \mathrm{~m} \mathrm{a}^{-1}$ for the Fennoscandian ice sheet, which is clearly fast, but not as fast as ice streams. A Quaternary example may be the Norfolk area of the pre-Weichselian British ice sheet (Hart and Boulton, 1991). The typical landform-sediment assemblage consists of deforming-bed till (and in places, drumlins and push moraines related to the deforming bed), but covering a broad swathe of the landscape and not confined to a valley-shaped area.

Given this definition of fast ice flow, it is then assumed that the landform-sediment assemblage associated with slow ice flow will exclude deforming-bed till, drumlins and push moraines associated with a deforming bed.

Identifying continuous and discontinuous fast flow from palaeo-ice streams

\section{Bed-flow type}

Many researchers have identified ice streams in the geological record by their spatial pattern (e.g. Kleman and others, 1997), their bed-flow type geomorphology (e.g. lineated subglacial landforms) and sometimes their associated deforming-bed till.

A key element in these studies is drumlins, which most researchers consider form as a component part of the deforming bed, from the diversion of flow around more-competent obstacles within the deforming layer (i.e. morecompetent till or sand bodies) (Boulton, 1987). Additionally, Hart (1997) suggested that drumlins form associated with net subglacial deforming-bed erosion during periods of increased velocity or decreased sediment supply. Unfortunately, there has been insufficient research on modern-day drumlins to record whether they form associated with continuous or discontinuous fast ice flow.

However, many authors have suggested that an increase in drumlin elongation ratio is due to an increase in glacier velocity (e.g. Hollingworth, 1931; Clark, 1994). The drumlins of New York State provide an example of these ideas. New 

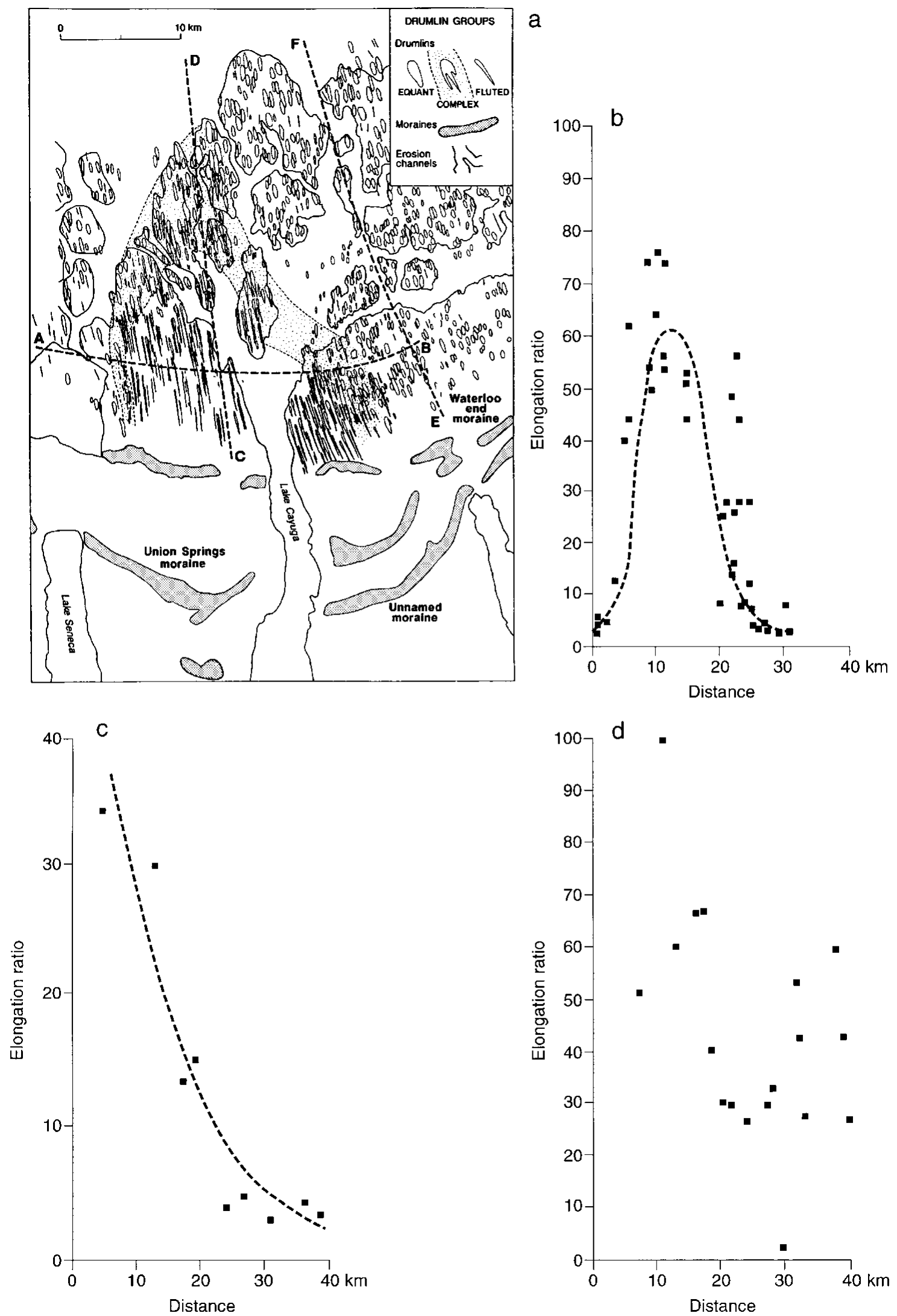

Fig. 4. Elongation ratio analysis from the Lake Cayuga area: a) detail of the southern area, with the different forms of drumlins (from Stahman, 1992); (b) graph of elongation ratio against distance across the megaflute fan (section AB); (c) graph of elongation ratio against distance from the ice margin within the megaflute fan (section DC); (d) graph of elongation ratio against distance from the ice margin outside the megaflute fan (section EF).

York State contains over 10000 drumlins which were formed beneath one of the southern lobes of the late Wisconsin Laurentide ice sheet (Fig. 3) (Slater, 1929; Muller, 1974). In particular, the lineations north of Lake Cayuga have been investigated in detail by Stahman (1992) (Fig. 4a). He showed that megaflutes become more elongated towards the centre of the fan (section AB in Fig. 4a, results in Fig. $4 \mathrm{~b}$ ); and increase in elongation towards the ice margin (sec- 
a


b

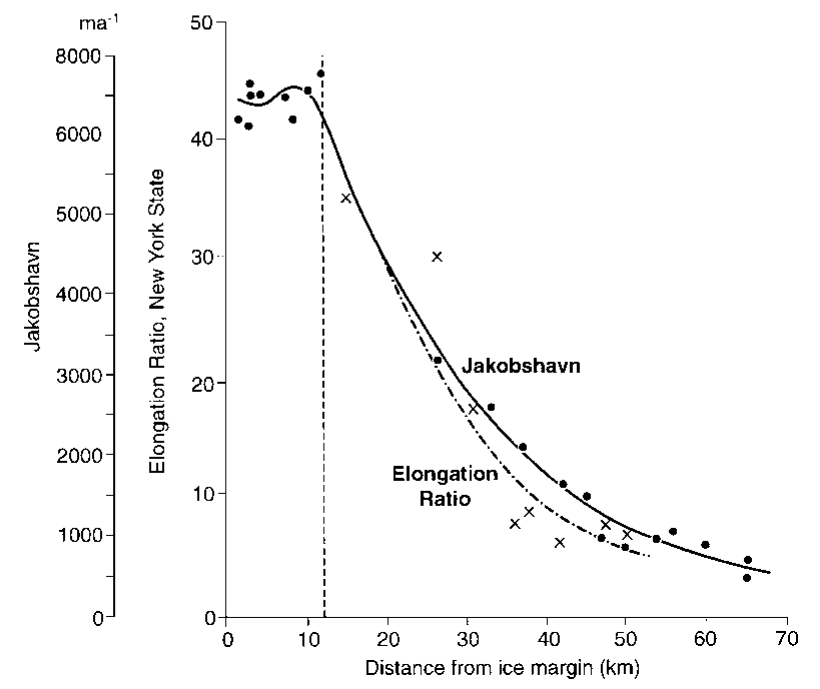

Fig. 5. Comparisons between the velocity of modern ice streams and the elongation ratio (proxy for velocity) for Laurentide ice streams (New York State): (a) Cross-sectional velocity profile of Jakobshavn Isbre (after Echelmeyer and Harrison, 1990; solid line), Ice Stream B (after Whillans and others, 1993; dashed line) and New York State (dotted and dashed line); ( b) Longitudinal velocity profile of Jakobshavn Isbre up-glacier of the grounding line (after Echelmeyer and Harrison, 1990; solid line) and New York State (dotted and dashed line).

tion DC in Fig. 4b, results in Fig. 4c). However, this increase in elongation does not occur in the drumlins to the side of the megaflute fan (section FE in Fig. 4b, results in Fig. 4d).

If elongation ratio is indeed related to ice velocity, then the proxy velocities from Lake Cayuga can be compared with some modern ice streams. Figure 5 shows the cross-sectional and longitudinal ice velocities from Jakobshavn Isbræ, (Echelmeyer and Harrison, 1990) and Ice Stream B, Antarctica (Whillans and others, 1993) superimposed on the drumlin elongation ratios from New York. It can be seen that the velocity changes are very similar in the three examples.

Thus, it would appear from the discussion above that drumlins probably reflect discontinuous fast ice flow (either in deforming-bed and/or ice-stream locations) and that there is a potential for proxy velocity reconstructions.

However, just as it was difficult at the valley-glacier scale to distinguish between surging glaciers and deforming-bed glaciers, it is difficult at the ice-sheet scale to distinguish between ice streams and the adjacent deforming-bed ice sheet. The best evidence for the existence of ice streams is the bed-type geomorphology aligned in a valley and/or fan shape; and drumlins that follow a predictable pattern, as illustrated above in the New York State example.

\section{Ice-thrust type}

Other palaeo-ice streams have been interpreted with a different geomorphology. Patterson (1997) described the Des Moines lobe (Fig. 3), which included push moraines (composed of thrust sheets), eskers (both subglacial and supraglacial) and widespread minor transverse ridges which have been interpreted to have formed associated with crevassed stagnating ice. She argued, in a similar way to Clayton and others (1985), that because the geomorphology is similar to modern surging glaciers, then these also reflect discontinuous ice streams. With reference to the discussion on geomorphology and surging glaciers above, it can be seen that the style of the Des Moines lobe is similar to the ice-thrust style of geomorphology and so may also reflect discontinuous fast ice flow. However, it is possible that this style of landform assemblage on this scale may simply reflect ice-sheet disintegration and so more studies of this style of geomorphology in the Quaternary record need to be carried out.

If the Des Moines lobe was formed by a discontinuous fast ice flow, then this style of geomorphology would indicate that a high percentage of subglacial sediment transport took place within the debris-rich basal ice layer and concords with the argument put forward by Alley and MacAyeal (1994): that the surging of a cold ice stream can allow debris to be frozen on to the glacier en mass. Similarly, it could be argued that in the bed-flow type of ice-sheet scale fast ice, most debris transport was within the deforming layer. However, in these two examples, the effect of the grain-size of the bed on geomorphological style (at ice-sheet scale) has not been assessed and requires further investigation.

\section{GONCLUSION}

Fast ice flow is a very important component of glacier dynamics and its presence and style is important in understanding past ice-sheet behaviour. Fast ice flow can be divided into two classes (Table 1): discontinuous ("surging" ice streams, surging valley glaciers, tidewater glaciers) and continuous ("steady" ice streams, deforming-bed fast icesheet flow and deforming-bed glaciers).

It was suggested from studies of the landform assemblage associated with modern valley glaciers that there are two styles of geomorphology associated with fast ice flow. Ice-thrust style landform assemblage (e.g. hummocky moraines and bulldozed push moraines associated with coarse-grained sedimentary environments) related with discontinuous fast ice flow, and bed-flow type landform assemblage (e.g. "squeeze" push moraines and subglacial bedforms associated with fine-grained sedimentary environments) related to both continuous and discontinuous (often distinguished by crevasses diapirs) ice flow.

On the ice-sheet scale, it is tentatively suggested that palaeo fast ice flow can be identified by: bed-flow and, with less certainty, ice-thrust geomorphologies. This flow is likely to represent a palaeo-ice stream if: (a) it is within an valley or fan-shaped form; and (b) there are predictable patterns of proxy velocity indicators (drumlins).

Thus, using evidence from modern examples of fast ice flow, it may be possible to reconstruct the spatial, and possibly temporal, aspects of Quaternary fast ice flow. It may also be 
possible from the study of landform assemblage to reconstruct debris transport paths within past ice sheets, which help with our general overall reconstruction of past glacier dynamics.

\section{ACKNOWLEDGEMENTS}

I would like to thank T. Aspden and his colleagues in the Cartographic Unit, Department of Geography for figure reproduction, and A. Jones for helpful comments on an earlier draft of the paper.

\section{REFERENCES}

Alley, R. B. 1991. Deforming-bed origin for southern Laurentide till sheets? f. Glaciol., 37(125), 67-76.

Alley, R. B. and D. R. MacAyeal. 1994. Ice-rafted debris associated with binge/purge oscillations of the Laurentide ice sheet. Paleoceanography, 9(4), 503-511.

Alley, R. B., D. D. Blankenship, C. R. Bentley and S. T. Rooney. 1986. Deformation of till beneath Ice Stream B, West Antarctica. Nature, 322(6074), 57-59.

Alley, R. B., K. M. Cuffey, E. B. Evenson, J. C. Strasser, D. E. Lawson and G. J. Larson. 1997. How glaciers entrain and transport basal sediment: physical constraints. Quat. Sci. Rev., 16(9), 1017-1038.

Bamber, J. L., R. J. Hardy and P. Huybrechts. 1997. Interpretation of balance velocities on the Greenland ice sheet. [Abstract.] EOS, 78(46), Fall Meeting Supplement, F15.

Boulton, G. S. 1979. Processes of glacier erosion on different substrata. F. Glaciol., $23(89), 15-38$.

Boulton, G. S. 1987. A theory of drumlin formation by subglacial sediment deformation. In Menzies, J. and J. Rose, eds. Drumlin Symposium. Rotterdam, A.A. Balkema, 25-80.

Boulton, G. S., G. D. Smith, A. S. Jones and J. Newsome. 1985. Glacial geology and glaciology of the last mid-latitude ice sheets. 7. Geol. Soc., London, $142(3), 447-474$.

Boulton, G. S. and 7 others. 1996. Till and moraine emplacement in a deforming bed surge - an example from a marine environment. Quat. Sci. Rev., $\mathbf{1 5}(10)$, 961-987.

Budd, W. F. and R. C. Warner. 1996. A computer scheme for rapid calculations of balance-flux distributions. Ann. Glaciol., 23, 21-27.

Clark, C. D. 1994. Large-scale ice moulding: a discussion of genesis and glaciological significance. Sediment. Geol., 91(1-4), 253-268.

Clarke, G. K. C. and E.W. Blake. 1991. Geometric and thermal evolution of a surge-type glacier in its quiescent state: Trapridge Glacier, Yukon Territory, Canada, 1969-89. F. Glaciol., 37(125), 158-169.

Clarke, G. K. C., S. G. Collins and D. E. Thompson. 1984. Flow, thermal structure, and subglacial conditions of a surge-type glacier. Can. F. Earth Sci., 21 (2), 232-240.

Clayton, L., J. T. Teller and J.W. Attig, Jr. 1985. Surging of the southwestern part of the Laurentide ice sheet. Boreas, 14(3), 235-241.

Croot, D. G. 1988. Glaciotectonics and surging glaciers: a correlation based on Vestspitsbergen, Svalbard, Norway. In Croot, D. G., ed. Glaciotectonics: forms and processes. Rotterdam, A. A. Balkema, 49-61.

Dahl-Jensen, D. 1989. Steady thermomechanical flow along two-dimensional flow lines in large grounded ice sheets. 7. Geophys. Res., 94(B8), $10,355-10,362$

Doake, C. S. M., R. M. Frolich, D. R. Mantripp, A. M. Smith and D. G. Vaughan. 1987. Glaciological studies on Rutford Ice Stream, Antarctica. 7. Geophys. Res., 92(B9), 8951-8960.

Dowdeswell, J. A. and 6 others. 1996. Large-scale sedimentation on the glacier-influenced polar North Atlantic margins - long-range side-scan sonar evidence. Geophys. Res. Lett., 23 (24), 3535-3538.

Echelmeyer, K. and W. D. Harrison. 1990. Jakobshavns Isbræ, West Greenland: seasonal variations in velocity - or lack thereof. f. Glaciol., 36(122), 82-88

Harbor, J., M. Sharp, L. Copland, B. Hubbard, P. Nienow and D. Mair. 1997. The influence of subglacial drainage conditions on the velocity distribution within a glacier cross section. Geology, 25(8), 739-742.

Hart, J. K. 1995a. An investigation of the deforming layer/debris-rich basal ice continuum, illustrated from three Alaskan glaciers. 7. Glaciol., 41 (139), 619-633.

Hart, J. K. 1995b. Recent drumlins, flutes and lineations at Vestari-Hagafellsjökull, Iceland. F. Glaciol., 41(139), 596-606.

Hart, J. K. 1997. The relationship between drumlins and other forms of subglacial glaciotectonic deformation. Quat. Sci. Rev., 16(1), 93-107.

Hart, J. K. and G. S. Boulton. 1991. The interrelation of glaciotectonic and glaciodepositional processes within the glacial environment. Quat. Sci. Rev., $10(4), 335-350$.

Hart, J. K. and B. Smith. 1996. Glacial geomorphology associated with surging glaciers, illustrated from Black Rapids Glacier. In Hart, J. K., ed. Alaska expedition 1995. Southampton, University of Southampton. Department of Geography, 53-71. (Discussion Paper 40.)

Hart, J. K. and B. Smith. 1997. Subglacial deformation associated with fast ice flow, from Columbia Glacier, Alaska. Sediment. Geol., 111(1-4), 177-197.

Hart, J. K. and R. Watts. 1997. A comparison of the styles of deformation associated with two recent push moraines, south Van Keulenfjorden, Svalbard. Earth Surf. Processes Landforms, 22(12), 1089-1107.

Hollingworth, S. E. 1931. Glaciation of western Edenside and adjoining areas and drumlins of the Edenside and Solway basin. O. 7. Geol. Soc. London, 87(3), 281-359.

Humphrey, N., B. Kamb, M. Fahnestock and H. Engelhardt. 1993. Characteristics of the bed of the lower Columbia Glacier, Alaska. 7. Geophys. Res., 98(B1), 837-846.

Iverson, N. R. 1993. Regelation of ice through debris at glacier beds: implications for sediment transport. Geology, 21(6), 559-562.

Iverson, N. R. and D. J. Semmens. 1995. Intrusion of ice into porous media by regelation: a mechanism of sediment entrainment by glaciers. f. Geophys. Res., 100 (B7), 10,219-10,230.

Kamb, B. and 7 others. 1985. Glacier surge mechanism: 1982-1983 surge of Variegated Glacier, Alaska. Science, 227 (4686), 469-479.

Kleman, J., C. Hättestrand, I. Borgström and A. Stroeven. 1997. Fennoscandian palaeoglaciology reconstructed using a glacial geological inversion model. f. Glaciol., 43(144), 283-299.

Lingle, C. S., T. J. Hughes and R. C. Kollmeyer. 1981. Tidal flexure of Jakobshavns glacier, West Greenland. 7. Geophys. Res., 86(B5), 3960-3968.

Meier, M. F. and A. Post. 1969. What are glacier surges? Can. F. Earth Sci., 6(4), Part 2, 807-817.

Meier, M. F. and A. Post. 1987. Fast tidewater glaciers. 7. Geophys. Res., 92(B9), 9051-9058.

Menzies, J. 1979. The mechanics of drumlin formation with particular reference to the change in pore-water content of the till. f. Glaciol., 22(87), 373-384.

Muller, E. H. 1974. Origins of drumlins. In Coates, D. R., ed. Glacial geomorphology. Binghamton, NY, State University of New York, 187-204.

Patterson, C. J. 1997. Southern Laurentide ice lobes were created by ice streams: Des Moines Lobe in Minnesota, U.S.A. Sediment. Geol., 111(1-4), 249-261.

Post, A. 1975. Preliminary hydrography and historic terminal changes of Columbia Glacier, Alaska. U.S. Geol. Surv. Hydrol. Invest. Atlas HA-559, 3 maps. (Scale 1:10,000.)

Reger, R. D., A. G. Sturmann andJ. E. Beget. 1993. Dating Holocene moraines of Black Rapids Glacier, Delta River valley, central Alaska Range. In Solie, D. N. and F. Tannian, eds. Short notes on Alaskan geology 1993. Fairbanks, AK, Alaska Division of Geological and Geophysical Surveys, 51-59. (Professional Report 113.)

Shabtaie, S. and C. R. Bentley. 1987. West Antarctic ice streams draining into the Ross Ice Shelf: configuration and mass balance. 7. Geophys. Res., 92(B2), 1311-1336. (Erratum: 7. Geophys. Res., 1987, 92(B9), 9451.)

Sharp, M. 1988. Surging glaciers: geomorphic effects. Prog. Phys. Geogr., 12(4), $533-559$.

Slater, G. 1929. The structure of drumlins on the south shore of Lake Ontario. N.Y. State Mus. Bull. 281, 3-19.

Smalley, I. J. and D. J. Unwin. 1968. The formation and shape of drumlins and their distribution and orientation in drumlin fields. F. Glaciol., 7(51), 377-390.

Stahman, D. A. 1992. Composition and shape of fluted and equant drumlins in north central New York drumlin field. (M.Sc. thesis, University of Lehigh.)

Whillans, I. M., J. Bolzan and S. Shabtaie. 1987. Velocity of Ice Streams B and C, Antarctica. 7. Geophys. Res., 92(B9), 8895-8902.

Whillans, I. M., M. Jackson and Y.-H. Tseng. 1993. Velocity pattern in a transect across Ice Stream B, Antarctica. f. Glaciol., 39(133), 562-572. 